kunnet observere hvor utrolig kraftig fedmedrivende en høy insulinproduksjon er. $\AA$ forsøke å slanke disse pasientene ved hjelp av mosjon og diett er nytteløst. Situasjonen minner om det man ser hos mennesker som må opereres for sin fedme fordi andre måter å gå ned i vekt på ikke nytter. Jeg tror derfor at Mysterud og mange andre har rett når de mener at vårt høye karbohydratinntak er en vesentlig årsak til fedmeproblemet i vår tid. Problemene med laktoseintoleranse er etter min mening betydelig overdrevet, men jeg er enig $i$ at det er uforståelig at så mange voksne mennesker med laktase angivelig har melkeintoleranse.

Mysterud skriver at mennesket trenger en lang tarm for å skaffe nok næring, spesielt fett til den store hjernen. Det er sikkert riktig at fettabsorpsjonen er viktig for hjernefunksjonen, men fettabsorpsjonen trenger egentlig ikke så lang tarm, spesielt ikke lang tykktarm. Tykktarmen har lite eller ingenting med fettabsorpsjonen å gjøre og denne delen av tarmen kan vi operere bort uten at det făr konsekvenser for hjernefunksjonen. Tar vi bort for mye tynntarm derimot, kan man få hjerneskade, iallfall hvis kolesterolnivået blir lavt nok. Tykktarmen gjør at vi også skal kunne spise «gress»» (være «altetende», omnivor). Ca. $20 \%$ av karbohydratene blir ikke fordøyd og absorbert i tynntarmen, men går videre til tykktarmen hvor de blir mat for bakterier som produserer gass og korte fettsyrer. Disse korte fettsyrene absorberes og berger noe energi som ellers ville gå tapt. Bakeriene i tykktarmen kan raskt tilpasse seg et endret karbohydratinntak, og jeg er redd for at overfôring av disse bakteriene med «langsomme» karbohydrater som for en stor del går til tykktarmen, også kan gi fedme. Det er ti ganger så mange bakterier i tarmen som det er celler i hele kroppen og denne rasktvoksende bakteriefloraen har sikkert evoluert sine måter å signalisere til kroppen at de vil ha mer mat - for å leve videre. Hvordan bakteriene ev. signaliserer egen «sultfølelse» er ikke kjent, men tykktarmsflora som gir fedme, er nylig beskrevet hos mus.

Mysterud skriver: «Evolusjonstenkning er beklagelig nok ikke integrert i den ernæringslæren som predikes av ledende ernæringsforskere i vestlige land, dette gjelder også Norge. Rådene som gis kan være en direkte årsak til mange av de omfattende helse- og adferdsproblemene vi sliter med i vestlige land.» Dette er alvorlig, og jeg vil anbefale boken til alle som ønsker å orientere seg om evulosjonsteorier og deres mulige betydning for sunt kosthold. For dem som ønsker å fordype seg videre, finnes det 283 referanser.

Universitetet i Bergen

\section{Mikrober i åpent hav}

Helmreich S

\section{Alien ocean}

Anthropological voyages in microbial seas. 403 s, ill. Berkeley, CA: University of California Press, 2009. Pris USD 25

ISBN 978-0-520-25062-8

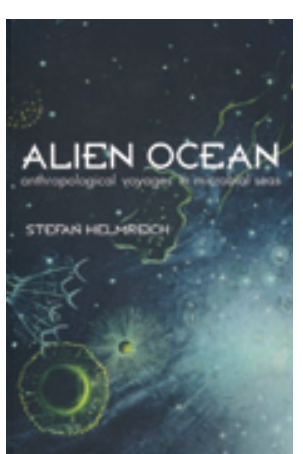

I den senere tid er det oppdaget at de åpne havområder inneholder uhorvelige mengder av mikroskopiske livsformer, kanskje 1000 ganger flere organismer per volumenhet enn forskere mente så sent som i 1980årene. Det er ikke bare antall individer som er høyt, også det biologiske mangfoldet er stort. Nye klasser organismer med overraskende stor genetisk og metabolsk variasjon oppdages kontinuerlig i vår tid. Hvor mange har for eksempel hørt om den nyoppdagede bakterien Prochlorococcus? Den er bare en mikrometer i omkrets, men tar igjen i antall hva den mangler i størrelse. Det er den mest vanlige fotosyntetiserende organisme på vår planet, og bidrar i vesentlig grad til karbonfiksering på Jorden. Fordi vi i så liten grad kjenner havets mest tallrike livsformer og deres økologiske betydning, er det fare for at vi i vår uvitenhet kan forårsake irreversible, alvorlige skader. Eksempler på dette er giftdumping, temperaturstigning, økende surhetsgrad og endringer i havstrømmer. Det er tross alt hav det er mest av på vår klode. Det er på denne bakgrunn vi må se bokens tittel, Alien ocean. Stefan Helmreich er ikke marinbiolog og heller ikke mikrobiolog. Hans fag er antropologi. Han skildrer liv og forskning ombord i dyptgående fartøyer og i marinbiologiske institutter på øyer i Stillehavet og i kystområder flere steder i verden. Boken bør leses som en samling frittstående essays og oversiktsartikler. En bonus er at vi blir kjent med så mange forskere og deres forskjellige syn på havets økologi.

Mikroorganismene kan grovt inndeles i tre hovedgrupper eller domener. Archae, tidligere kaldt archebakterier, omfatter bl.a. de ekstremofile mikrober og er evolusjonsmessig de eldste livsformer på kloden. De er metabolsk og strukturelt annerledes enn de egentlige bakterier, eubakterier, som er den andre hovedgruppen. Den tredje gruppen er eukaryoter som har distinkte cellekjerner. Ved hjelp av metoder som strømningscytometri og polymerasekjedereaksjoner kan vi nå utforske havets mikroskopiske liv og genetiske mangfold raskere og mer effektivt enn noen gang før. Molekyler fra bakterier i havet har vist seg å kunne drepe patogene mikrober og enkelte typer kreftceller. Flere av dem som kommer til orde i boken mener at mange av de mikrobegenomer som nå blir avslørt, representerer «økologigener» som kan bidra til å forklare dynamikken og interaksjonene mellom organismer. Havet ses på som et nettverk av gener. Overføring av gener mellom forskjellige arter skjer bl.a. ved hjelp av virus. Hvor nyttig en rent genetisk kartlegging av havet vil vise seg å være, er vel et åpent spørsmål. Det er tross alt hver enkelt mikrobes totale genkomplement som bestemmer dens fysiologiske responskapasitet og dens interaksjon med andre livsformer. Et spesielt problem som preger mye moderne forskning er den store analysekapasiteten. Den gir oss så mye informasjon at det blir mer enn vanskelig å sette sammen enkeltobservasjoner til forståelige fysiologiske og biokjemiske mønstre. Den overveldende mengden informasjon er i seg selv et økologisk problem. Noen informasjonsbrokker er viktigere enn andre, men hvilke det er, finner vi kanskje ut i seneste laget.

\section{Anton Hauge}

Avdeling for fysiologi

Institutt for medisinske basalfag

Universitetet i Oslo

\section{Dyrelivets utvikling}

Minelli A.

Perspectives in animal phylogeny \& evolution 345 s, tab, ill. Oxford: Oxford University Press, 2009. Pris GBP 35

ISBN 978-0-19-856621-2

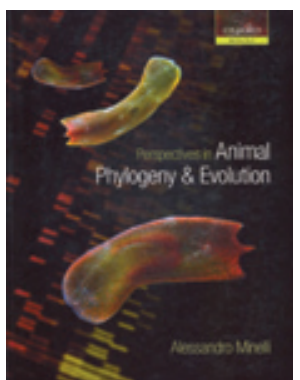

Alessandro Minelli er utviklingsbiolog ved universitetet i Padua. I denne boken slår han opp det helt store lerret, nemlig de flercellede dyrs struktur (phylogeny) og de utviklingsmekanismer som ligger

til grunn for strukturvariasjonene. Dette forskningsfeltet er under stadig endring, så Minelli bruker med rette ordet «perspectives» i boktittelen i stedet for en betegnelse som innebærer sikker kunnskap. Først omtales hver for seg evolusjonære mønstre og prosesser, i denne rekkefølgen. Det gir den interesserte leser et grunnlag for å forstå og følge hans mange eksempler på årsaks- og virkningskjeder både i utviklingen av det enkelte individs organer og utviklingen av nye arter.

Forfatteren stiller seg skeptisk til mange av de fylogenetiske trær med forgreninger 